\title{
Communication
}

(Comunicação)

\section{Occurrence of Haplometroides odhneri (Trematoda, Digenea, Plagiorchiidae) infecting Leptotyphlops koppesi (Serpentes, Leptotyphlopidae)}

[Ocorrência de Haplometroides odhneri (Trematoda, Digenea, Plagiorchiidae) parasitando Leptotyphlops koppesi (Serpentes, Leptotyphlopidae)]

\author{
R.J. Silva', E.O.P. Zica', M. Cruz ${ }^{2}$, J.C. O'Reilly ${ }^{3}$, M.C. Costa ${ }^{4}$ \\ ${ }^{1}$ Departamento de Parasitologia - Instituto de Biociências - UNESP \\ Distrito de Rubião Júnior \\ 18618-000 - Botucatu, SP \\ ${ }^{2}$ Centro de Estudos e Pesquisas Biológicas - Universidade Católica de Goiás - Goiânia, GO \\ ${ }^{3}$ Department of Biology - University of Miami - Coral Gables, FL \\ ${ }^{4}$ Systema Naturae Consultoria Ambiental Ltda - Goiânia, GO
}

The Haplometroides genus belongs the subfamily Styphlodorinae, family Plagiorchiidae (Travassos et al., 1969; Yamaguti, 1971). Three trematode species are included in this genus: 1) H. buccicola (Odhner, 1911; Ruiz and Perez, 1959), 2) H. odhneri (Ruiz and Perez, 1959; Silva and Barrella, 2002) and 3) H. rappiae (Szydat, 1932).

The aim of this study was to report the occurrence of $H$. odhneri in specimens of Leptotyphlops koppesi. The voucher host snakes were from the Corumbá I Hydroeletric Power Plant, Caldas Novas city, Goiás State, Brazil. These animals were preserved properly and deposited in the Herpetological Collection of the Centro de Estudos de Pesquisas Biológicas, Universidade Católica de Goiás. Preserved specimens were necropsied and the trematodes were collected from the trachea and esophagus of three snakes (CEPB4482 - N=10; CEPB4483 $\mathrm{N}=3$; CEPB4484 - $\mathrm{N}=16$ ). Helminths were transferred to AFA solution without flattening, stained with carmine, clarified with creosote, and mounted in Permount resin. Morphometric analysis was performed using the Leica Qwin Lite 2.5 computerized system. All measurements were reported as the mean and range for four specimens.
The characteristics of the trematodes (Figure 1) were: body elongated, spined, flattened, with $4408 \mu \mathrm{m}$ (3637-5611) length and $1055 \mu \mathrm{m}$ (9461188 ) width, with maximum breadth at about the equatorial region. Oral sucker subterminal, $377 \mu \mathrm{m}$ (293-428) long and $389 \mu \mathrm{m}$ (343-434) wide. Prepharynx was not observed. Muscular pharynx $177 \mu \mathrm{m}(142-202)$ long and $177 \mu \mathrm{m}$ (163192) wide. Esophagus $274 \mu \mathrm{m}$ (235-310) long. Intestinal ceca not very sinuous, slightly unequal, with smooth walls, being distributed until the testicular region. Acetabulum pre-equatorial,

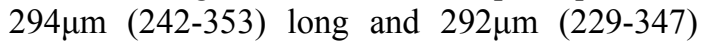
wide. Genital pore pre-acetabular, postbifurcal, submedian, opening up on the right cecal branch. Cirrus pouch relatively small, with elongated cirrus, located below the acetabulum, with curvature opposed beside the ovary. Testes ovoid, with irregular contours, in a diagonal position, postacetabular, intercecal. Anterior testis $361 \mu \mathrm{m}$ (266-445) long and $275 \mu \mathrm{m}$ (231356) wide, and posterior testis $356 \mu \mathrm{m}$ (211-451) long and $348 \mu \mathrm{m}$ (224-419) wide. Ovary just behind the acetabulum, ovoid, with regular contours, pre-testicular, lateral, intercecal, measuring $267 \mu \mathrm{m}$ (218-310) long and $230 \mu \mathrm{m}$ (191-282) wide. Mehlis' gland located below and to the right of the ovary. Seminal receptacle located below Mehlis' gland. Vitellaria

Recebido para publicação em 1 de abril de 2004

Recebido para publicação, após modificações, em 13 de setembro de 2004

E-mail: reinaldo@ibb.unesp.br 
consisting of developed not very numerous follicles in bunch shape, in a lateral position, extracecal, distributed from the zone of the genital pore to the testicular zone. Uterus well developed, occupying most of the post-testicular region and presenting branches that reach the medium zone. Vagina long and narrow. Eggs $44 \mu \mathrm{m}$ (38-48) long and $24 \mu \mathrm{m}(20-31)$ wide. Excretory pore terminal.

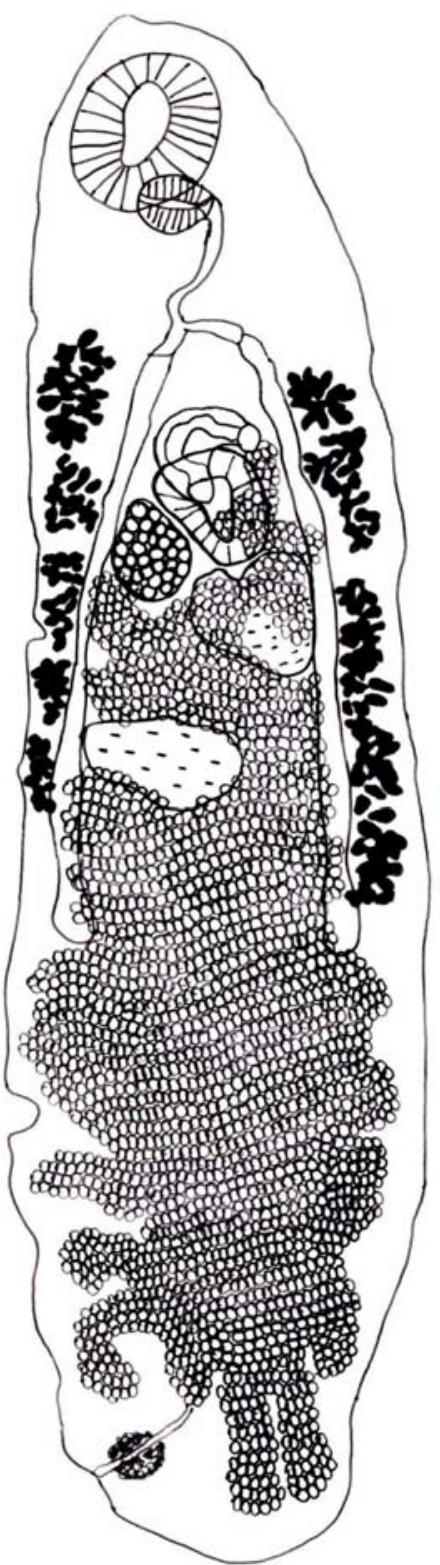

Figure 1. Haplometroides odhneri (Trematoda, Digenea, Plagiorchiidae) from the trachea and esophagus of Leptotyphlops koppesi (Serpentes, Leptotyphlopidae). Drawings prepared by P. A. Andrade and H. A. Monteiro e Silva $($ Bar scale $=500 \mu \mathrm{m})$.

The occurrence of trematodes in Leptotyphlops spp. snakes has not been previously reported. This is the first report of Leptotyphlops sp. as a host for trematodes and the first description of $L$. koppesi as a host for H. odhneri.

The species $O$. odhneri described in this article agrees with the data presented by Ruiz and Perez 
(1959). Compared with the species O. buccicola, the trematodes presented smaller dimensions, the acetabulum was more developed, the esophagus was shorter, the tegument presented more spines and the genital pore was more lateral. However, the vitellines of the studied specimens reach the testicular area and no ovarian area as mentioned by these authors.

For the snake group, the species of the Haplometroides genus were described parasitizing species of the Elapidae (Odhner, 1911; Ruiz and Perez, 1959; Silva and Barrella, 2002) and Boidae (Ruiz and Perez, 1959) families. The Micrurus species (family Elapidae) mentioned as hosts of Haplometroides spp. are preferentially ophiophagus and of fossorial habits while the species of the Epicrates genus (family Boidae) are of terrestrial habits, living on the soil and in shaded places, but they can also be found on tree trunks and branches, and feed of birds and small mammals. The species of the Leptotyphlops genus (family Leptotyphlopidae) have fossorial habits and feed preferentially on small insects, termites and ants (Silva, 2000). In spite of the wide diversity of feeding habits and environments occupied by these snakes, all are parasitized by trematodes of the Haplometroides genus, showing the great potential of parasite adaptation to the host.

Keywords: Serpentes, Leptotyphlops koppesi, Leptotyphlopidae, Haplometroides odhneri, Trematoda

\section{RESUMO}

Descreveu-se a ocorrência de Haplometroides odhneri (Trematoda, Digenea, Plagiorchiidae) na traquéia e esôfago de Leptotyphlops koppesi (Serpentes, Leptotyphlopidae) proveniente da Usina Hidrelétrica Corumbá I, município de Caldas Novas, Goiás. Este é o primeiro relato sobre a ocorrência de H. odhneri parasitando L. koppesi.

Palavras-chave: serpentes, Leptotyphlops koppesi, Leptotyphlopidae, Haplometroides odhneri, Trematoda

\section{ACKNOWLEDGEMENTS}

We are indebt to Prof. Dr. Nelson Jorge da Silva Junior and Prof. M.Sc. Hélder Lúcio Rodrigues Silva, for the identification of the species Leptotyphlops koppesi. We also thank Norma P. Villela (FURNAS - Centrais Elétricas S.A.) who provided all logistic support to the faunal rescue operation of Corumbá I and permitted the scientific use of these data

\section{REFERENCES}

ODHNER, T. Nordostafrikanische Trematoden gösstenteils von Weissen Nil (von der Schwedischen Zoologischen Expedition gesammelt). Res. Swed. Zool. Exp. Egypt. White Nile, v.4, p.1-166, 1911.

RUIZ, J.M.; PEREZ, M.D. Gênero Haplometroides. Redescrição da espécie-tipo e descrição de $H$. odhneri sp. n. (Trematoda: Plagiorchiidae). An. Fac. Farm. Odontol. Univ. São Paulo, v.16, p.87-91, 1959.

SILVA, R.J. As serpentes. Jaboticabal: Funep, 2000. 141p.

SILVA, R.J.; BARRELLA, T.H. Micrurus frontalis as a new host recorded for Haplometroides odhneri (Trematoda, Digenea, Plagiorchiidae). Rev. Bras. Parasitol. Vet., v.11, p.47-48, 2002.

SZYDAT, L. Parasiten aus Liberia und Französisch-Guinea. II. Teil: Trematoden. Zeits. Parasitenk., v.4, p.506-521, 1932.

TRAVASSOS, L.; FREITAS J.F.T.; KOHN, A. Trematódeos do Brasil. Mem. Inst. Oswaldo Cruz, v.67, p.1-886, 1969.

YAMAGUTI, S. Synopsis of digenetic trematodes of vertebrates, V.I-II., Tokyo, Japan: Keigaku, 1971. 1555p. 